\title{
運動 線毛と一次線毛
}

萩 原 治 夫 ${ }^{1}$

\section{1.はじめに}

線毛は，細胞表面の細長い突起で，運動線毛 (motile cilia) と一次線毛 (primary cilia) の 2 種類に分類される (図 1 ). 線毛細胞は，百数十本の運動線毛をもった細胞 で, 気道上皮や生殖器系の上皮に見られる. 線毛運動に より, 気道では異物が除去され, 女性生殖器では卵子が 子宮に向かって輸送される。

線毛は基底小体から伸長する. 基底小体は，中心子と 同じ構造をしているので, 線毛細胞でなくても, 中心子 から線毛が形成されることがある。これが一次線毛であ る.一次線毛は, 運動能がないと考えられ, 長い間注目さ れることがなかったが, 近年その重要な役割が明らかに なってきた. 運動線毛と一次線毛の形態学, 一次線毛の 機能, 線毛発生とその異常について, 私自身の研究も含 めて紹介する.

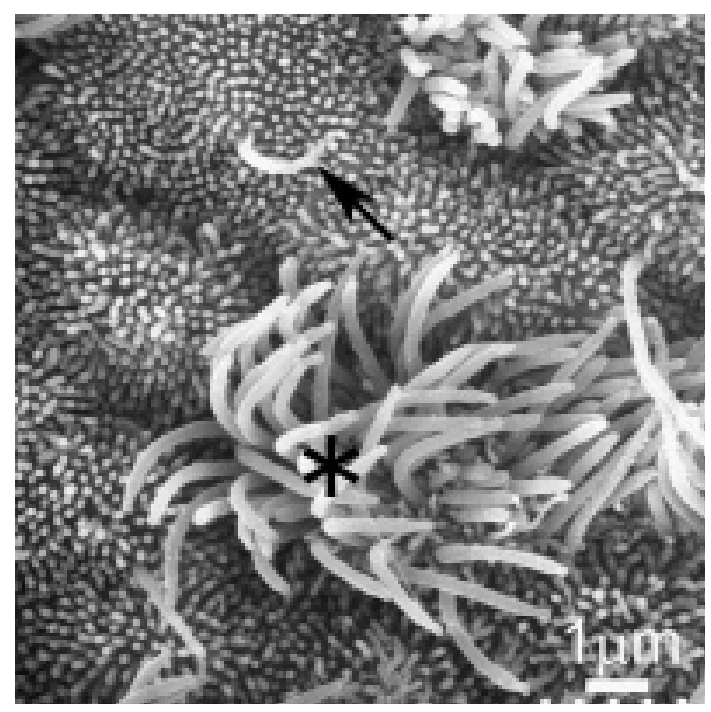

図 1 七ト卵管上皮の走査型電子顕微鏡写真. ※印は, 線毛細胞の運動線毛である. 矢印は, 分泌細胞の一次線 毛で, 細胞から線毛が一本だけ伸長している.

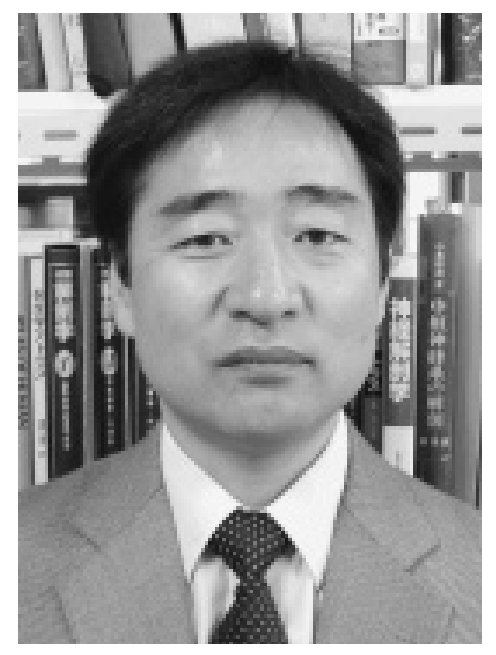

\section{2. 運動線毛と一次線毛の形態学的解析}

線毛の内部では, 微小管が規則正しく配列してアクソ ネームを形成している. 運動線毛のアクソネームは, 2 本 の中心微小管と，9個の 2 つ組の周辺微小管から構成さ れ,これを 9+2 配列という. 周辺微小管には, ATPase 活 性を持つダイニン腕が付属し, 線毛運動に関与している. 一方, 一次線毛のアクソネームは, 9+0配列で中心微小 管を欠き, 胎児のノード (発生初期の胚の中央表面にで きる浅い寉み）に見られるものをのぞいて, ダイニン腕 も無い.

細胞には, 中心子がペアで存在し, それぞれ母中心子, 娘中心子という. 細胞分裂時に, 2 個の中心子は複製され て4個になるが，もとからあった方が母中心子で，新し くできた方が娘中心子である. 母中心子と娘中心子の周 囲物質の分子構成には著しい違いがあり, ${ }^{1}$ 一次線毛は, 母中心子から伸長する.

\section{3. 一次線毛の機能}

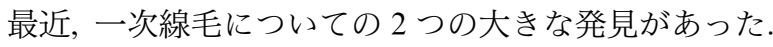
ひとつは, 胎児のノードに出現する一次線毛は, ダイニ ン腕を有し渦状の回転運動を行い,ノード内の分子の濃

1 群馬県前橋市昭和町3-39-22 群馬大学大学院医学系研究科器官代謝制御学講座生体構造解析学分野 平成19年11月29日 受付

論文別刷請求先 $\overline{\mathbf{T}} 371-8511$ 群馬県前橋市昭和町3-39-22 群馬大学大学院医学系研究科器官代謝制御学講座生体構造解析学分野 萩原治夫 
度に左右差を生じさせて体の左右軸の形成に関与してい ることである. ${ }^{2}$ Kartagener 症候群では, ダイニンの異常 により，ノードの一次線毛の運動が障害される。このた めに左右軸の形成が正常に起こらず，内臟逆位を生じる. もう一つの発見は, 腎臟の尿細管上皮の一次線毛は, 尿 細管中の原尿の流机を感知するセンサーとして働き, 細 胞内のシグナル伝達に密接に関係して腎臟の形態形成に 関与していることである. ${ }^{3}$ 尿細管上皮の一次線毛にはポ リシスティン分子が存在し，ポリシスティンの遺伝子異 常により一次線毛の形成不全が起こり, 多発性囊胞腎が 発症することが明らかになっている。

一次線毛は, 尿細管や胎児のノード以外にも，様久な 器官の多種類の細胞に出現する. 胎児のノードや尿細管 の一次線毛が重要な働きをしていることが明らかとな り,これら以外の細胞の一次線毛の働きも注目されるよ うになった. 軟骨細胞の一次線毛は, 基質の圧を感じ 取って軟骨形成に関係していると考元られ，脺臟外分泌 部の分泌細胞の一次線毛は, 分泌顆粒の放出に関与して いると考元られている. 私は, 線維芽細胞に打ける一次 線毛の機能的意義についての研究を進めている. 細胞に とって無意味な構造はない. 今後, 様及な細胞型におけ る一次線毛の役割が解明されることだろう.

\section{4. 線毛発生と炎の異常}

線毛を伸長した基底小体には，付属構造が付随してい る. 線毛, 基底小体, 基底小体付属構造の 3 者をまとめて, 線毛装置という。線毛装置の形成を線毛発生 (ciliogenesis) といい, 1. 中心子の複製, 2. 複製中心子の移 動による基底小体の形成，3.線毛の伸長，4. 基底小体付 属構造の形成, という 4 段階からなる. 線毛発生, 特に基 底小体付属構造の構築機構について解析し, 線毛発生に 特異的な構造を新たに発見した. ${ }^{4}$

線毛の異常には，線毛運動機能不全症候群（immotile cilia syndrome) のように, 遺伝子異常による一次性の異 常と, 複合線毛のように, 炎症などが原因となる二次性
の異常がある.ヒトの線毛発生についての解析により, 各段階における線毛発生の障害が二次性の線毛異常と密 接に関係していることを明らかにした. ${ }^{4}$

\section{5.おわりに}

基底小体に付属する構造の一つに，根小毛がある，根 小毛は, 基底小体から核にむかって伸びる細線維の束で, 周期性の横紋をもち, 基底小体を細胞先端部につなぎと める働きをしている. ${ }^{5}$ 根小毛の構成分子として, 数年前 にルートレチンが同定されたが, 基底小体付属構造の構 成分子や形成機構については多くの点が未解明である. 現在，根小毛を認識する抗体などを利用して，根小毛形 成の分子構築について研究を進めている. 線毛細胞への 分化を誘導・制御している分子機構の解明により，将来 的に, 線毛や細胞の運動の異常が原因となる疾患の予 防・治療法の開発にも寄与したいと考えている.

\section{6. 文献}

1. Hagiwara H, Tajika Y, Matsuzaki T, Suzuki T, Aoki T, Takata K. Localization of Golgi $58 \mathrm{~K}$ protein (formiminotransferase cyclodeaminase) to the centrosome Histochem Cell Biol 2006; 126 : 251-259.

2. Buceta J, Ibañes M, Rasskin-Gutman D, Okada Y, Hirokawa N, Izpisúa-Belmonte JC. Nodal Cilia Dynamics and the Specification of the Left/Right Axis in Early Vertebrate Embryo Development. Biophysical Journal $2005 ; 89:$ 2199-2209.

3. Nauli SM, Zhou J. Polycystins and mechanosensation in renal and nodal cilia. Bioessays. 2004; 26: 844856.

4. Hagiwara H, Ohwada N, Takata K. Cell biology of normal and abnormal ciliogenesis in the ciliated epithelium. Int Rev Cytol. 2004 ; 234 : 101-141.

5. Hagiwara $\mathrm{H}$, Aoki $\mathrm{T}$, Kano $\mathrm{T}$, Ohwada N. Immunocytochemistry of the striated rootlets associated with solitary cilia in human oviductal secretory cells. Histochem Cell Biol 2000; 114 : 205-212. 